\title{
Potential application of protease isolated from Pseudomonas aeruginosa PD100
}

\author{
Mohsen Fathi Najafi* \\ Razi Institute \\ Next to Hotel Homa, Ahmadabad street \\ Mashad, Iran \\ Tel: $985118431780 / 8418114$ \\ Fax: 985118420430 \\ E-mail: najafi99@yahoo.com \\ Dileep Deobagkar \\ The Molecular Biology Research Laboratory \\ Department of Zoology \\ University of Pune \\ Ganeshkhind, Pune-411007, Maharashtra, India \\ Tel: 912052698432 \\ Fax:91 2052690617 \\ E-mail: dddeo@unipune.ernet.in \\ Deepti Deobagkar \\ The Molecular Biology Research Laboratory \\ Department of Zoology \\ University of Pune \\ Ganeshkhind, Pune-411007, Maharashtra, India \\ Tel: 912052698432 \\ Fax:91 2052690617 \\ E-mail: dddeo@unipune.ernet.in
}

Financial support: Government of India and Iran.

Keywords: blood clot, protease, Pseudomonas aeruginosa PD100, SDS, solvent.

A protease isolated from Pseudomonas aeruginosa PD100 could act in the presence of SDS and Tween 80. This protease could be useful for degradation of protein in the presence of solvent, dehairing of cow skin and degradation of natural proteins. The immobilized protease showed $15-20 \%$ increases in temperature stability and the entrapped enzyme retained $83 \%$ of its initial activity after six cycles. With respect to properties of the enzyme and its capability for degradation of different protein sources, this protease finds potential application for waste treatment, used in detergents and leather industry.

Proteases execute a large variety of functions and have important biotechnological applications. Proteases represent one of the three largest groups of industrial enzymes and find application in detergents, leather industry, food industry, pharmaceutical industry and bioremediation processes (Anwar and Saleemuddin, 1998; Gupta et al. 2002). Probably the largest application of proteases is in laundry detergents, where they help removing protein based stains from clothing (Banerjee et al. 1999). For an enzyme to be used as an detergent additive it should be stable and active in the presence of typical detergent ingredients, such as surfactants, builders, bleaching agents, bleach activators, fillers, fabric softeners and various other formulation aids. In textile industry, proteases may also be used to remove the stiff and dull gum layer of sericine from the raw silk fibre to achieve improved luster and softness. Protease treatments can modify the surface of wool and silk fibres to provide new and unique finishes. Proteases have been used in the hidedehairing process, where dehairing is carried out at $\mathrm{pH}$ values between 8 and 10 .

An interesting application of alkaline protease was developed by Fujiwara and coworkers (Ishikawa et al. 1993). They reported the use of an alkaline protease to decompose the gelatinous coating of X-ray films, from which silver was recovered. Proteases are also useful and important components in biopharmaceutical products such as contact-lens enzyme cleaners and enzymic debriders (Anwar and Saleemuddin, 2000). The proteolytic enzymes also offer a gentle and selective debridement, supporting the natural healing process in the successful local management of skin ulcerations by the efficient removal of the necrotic material (Sjodahl et al. 2002).

*Corresponding author 
Table 1. Purification table for protease of $P$. aeruginosa PD100.

\begin{tabular}{|c|c|c|c|c|c|}
\hline Step & $\begin{array}{c}\text { Total activity } \\
\text { (unit) }\end{array}$ & $\begin{array}{c}\text { Total protein } \\
\text { (mg) }\end{array}$ & $\begin{array}{c}\text { Specific activity } \\
\text { (U/mg) }\end{array}$ & $\begin{array}{c}\text { Purification } \\
\text { (fold) }\end{array}$ & $\begin{array}{c}\text { Yield } \\
\text { (\%) }\end{array}$ \\
\hline Culture supernatant & 2232 & 318 & 7 & 1 & 100 \\
\hline Ammonium sulfate & 1600 & 63.4 & 25 & 12 & 72 \\
\hline Sephadex G-50 & 1392 & 16.6 & 84 & 49 & 38 \\
\hline CM-Sephadex & 858 & 2.5 & 343 & 38 \\
\hline
\end{tabular}

Although proteases are widespread in nature, microbes serve as a preferred source of these enzymes because of their rapid growth, the limited space required for their cultivation and the ease with which they can be genetically manipulated to generate new enzymes with altered properties that are desirable for their various applications. In an earlier study we have isolated $P$. aeruginosa $P D 100$ which produces one protease (confirmed by Acidic-NativePAGE and Native-PAGE). With respect to properties of this protease, it was considered of interest to investigate further the potential of the $P$. aeruginosa PD100 protease, in particular as an additive in various bio-formulations such as biological detergents, dehairing, amino acid production and contact-lens cleansing agents. In this paper we present potential application of the protease for different industrial proposes.

\section{MATERIALS AND METHODS}

\section{Materials}

The protease was isolated from Pseudomonas aeruginosa PD100 and was used for this work. Ethylenediaminetetra- acetate (EDTA), Sodium dodecyl sulfate (SDS), formaldehyde, Tween 80, ammonium per sulfate (APS), $\mathrm{N}, \mathrm{N}, \mathrm{N}^{\prime}, \mathrm{N}^{\prime}-\mathrm{Tetramethylethlen} \mathrm{diamin} \mathrm{(TEMED);} \mathrm{all}$ chemicals were from Sigma. All other chemicals used were of analytical grade.

\section{Protease assay}

The protease activity was spectrophotometrically assayed according to Kunitz (Kunitz, 1947) with some modifications. The reaction was carried out in a reaction mixture containing $450 \mu \mathrm{l}$ of $1 \%(\mathrm{w} / \mathrm{v})$ casein or hemoglobin with $50 \mathrm{mM}$ Tris- $\mathrm{HCl}(\mathrm{pH} 8)$ and $50 \mu \mathrm{l}$ of the diluted enzyme for $20 \mathrm{~min}$ incubation at $55^{\circ} \mathrm{C}$. The reaction was stopped by adding $750 \mu \mathrm{l}$ of TCA solution [5\% (w/v) TCA, $9 \%(\mathrm{w} / \mathrm{v})$ Na-acetate, $9 \%(\mathrm{v} / \mathrm{v})$ acetic acid], followed by $30 \mathrm{~min}$ incubation at room temperature and centrifugation $(15000 \mathrm{x} \mathrm{g}, 15 \mathrm{~min})$. The absorbance of the soluble peptide (supernatant) was measured at $280 \mathrm{~nm}$. One unit of the enzyme activity was defined as the amount of enzyme which releases $1 \mu \mathrm{mol}$ of tyrosine per min under the assay conditions.

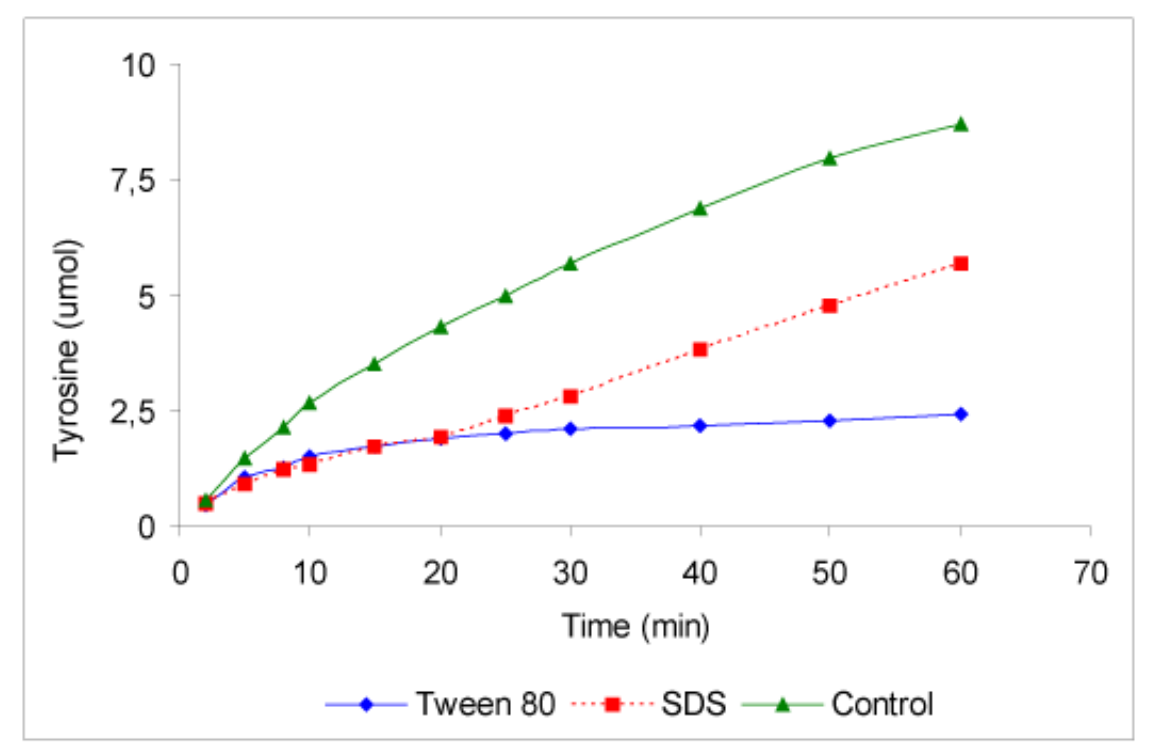

Figure 1. Effect of SDS and Tween 80 on protease. The enzyme was incubated with $1 \%(w / v)$ SDS and $3 \%(v / v)$ Tween 80 along with $1.5 \%(\mathrm{w} / \mathrm{v})$ casein in $50 \mathrm{mM}$ Tris- $\mathrm{HCl}(\mathrm{pH} 8)$ at $50^{\circ} \mathrm{C}$. Aliquots were removed at different time intervals and the amount of tyrosine released was determined according to standard method. 
Table 2. Properties of the protease from Pseudomonas aeruginosa PD100.

\begin{tabular}{|l|l|}
\hline \multicolumn{1}{|c|}{ Property } & \\
\hline Molecular weight by: & \\
Sephadex G-50 & 38000 \\
SDS-PAGE & 36000 \\
\hline Number of protease & One protease was secreted by the organism (confirmed by Acidic-Native-PAGE and \\
\hline Carbohydrate content & Native-PAGE) \\
\hline pl & $\mathrm{NIL}$ \\
\hline Optimum $\mathrm{pH}$ & 6.2 \\
\hline $\mathrm{pH}$ stability & 8 \\
\hline Optimum temperature & $\mathrm{pH} 6.5-11$ for $24 \mathrm{~h}$ at $4^{\circ} \mathrm{C}$ \\
\hline Temperature stability & $60^{\circ} \mathrm{C}$ \\
\hline Metal ion requirement & $55^{\circ} \mathrm{C}$ for 60 min \\
\hline Inhibitors & $\mathrm{NIL}$ \\
\hline Mode of action & $\mathrm{Ag}^{2+}, \mathrm{Ni}^{2+}, \mathrm{Cu}^{2+}, \mathrm{Zn}^{2+}, \beta-\mathrm{ME}, \mathrm{DTNB}$, iodoacetamide, DEPC,HNBB,NEM \\
\hline Substrate specificity & $\mathrm{Endo}^{2}$ \\
\hline Auto digestion & $\mathrm{collagen}>$ fibrin> azocasein> casein> hemoglobin> BSA> ovalbumin> elastin \\
\hline
\end{tabular}

\section{Purification of protease}

The microorganism was grown for $24 \mathrm{hrs}$ in CYKN medium $[1 \%(\mathrm{w} / \mathrm{v})$ casein, $0.5 \%(\mathrm{w} / \mathrm{v})$ yeast extract, $0.2 \%$ $(\mathrm{w} / \mathrm{v}) \mathrm{K} 2 \mathrm{HPO} 4,0.5 \%(\mathrm{w} / \mathrm{v}) \mathrm{NaCl}$ and $\mathrm{pH}$ 7.5]. The cells were harvested by centrifugation at $10000 \mathrm{rpm}$ for $10 \mathrm{~min}$ at $25^{\circ} \mathrm{C}$, and the supernatant was used as the starting point for purification as follow:

Ammonium sulfate precipitation. $100 \mathrm{ml}$ of the supernatant was used for precipitation with $70 \%$ ammonium sulfate. All subsequent steps were carried out at 4 o C. The resulting precipitate was collected by centrifugation at $15000 \mathrm{x} \mathrm{g} 30 \mathrm{~min}$ at $4^{\circ} \mathrm{C}$. The precipitate was dissolved in $20 \mathrm{mM}$ Tris- $\mathrm{HCl}(\mathrm{pH} 8)$ and used for gel filtration chromatography.

Sephadex G-50 chromatography. The enzyme obtained from the above step was loaded onto a Sephadex G-50 column $(1.2 \times 135 \mathrm{~cm})$, pre-equilibrated with $50 \mathrm{mM}$ Tris$\mathrm{HCl}(\mathrm{pH} 8)$, at a flow rate of $10 \mathrm{ml} / \mathrm{h}$. Fractions of $3.5 \mathrm{ml}$ were collected and those having specific activity more than $70 \mathrm{U} / \mathrm{mg}$ were pooled and used for CM Sephadex chromatography.

CM-Sephadex chromatography. The partially purified enzyme obtained from Sephadex G-50 chromatography was adsorbed onto a CM-Sephadex column $(2 \times 15 \mathrm{~cm})$, preequilbrated at $\mathrm{pH} 5$ with $50 \mathrm{mM}$ citrate buffer. The column was washed with the same buffer till the effluent showed no protease activity. The bound enzyme was then eluted with a stepwise of $\mathrm{NaCl}(0.1-0.6 \mathrm{M})$ in $50 \mathrm{mM}$ citrate buffer, $\mathrm{pH}$ 5. Fractions of $5 \mathrm{ml}$ were collected and those having specific activity above $320 \mathrm{U} / \mathrm{mg}$ were pooled, dialyzed extensively against $50 \mathrm{mM}$ Tris- $\mathrm{HCl}(\mathrm{pH}$ 8), concentrated by lyophilization and stored at $-20^{\circ} \mathrm{C}$. Protein concentration was determined by Lowry method (Lowry et al. 1971).

\section{Effect of SDS and Tween 80}

The purified enzyme $(5 \mathrm{U}, 15 \mu \mathrm{g})$ was incubated with different concentrations of SDS and Tween 80 for $1 \mathrm{hr}$ and then assayed in the presence and absence of the detergents. Stability of the enzyme after treatment with both detergents was determined by protease assay and zymography, using $12.5 \%(\mathrm{w} / \mathrm{v})$ SDS-PAGE (Laemmli, 1970) and casein agar plate for zymography. The protease samples were loaded along with sample dye contained $1 \%(\mathrm{w} / \mathrm{v})$ SDS. After electrophoresis the gel was washed with $1 \%(\mathrm{v} / \mathrm{v})$ Triton X100 in $50 \mathrm{mM}$ Tris- $\mathrm{HCl}$ buffer $(\mathrm{pH} 8)$ for $10 \mathrm{~min}$ and sandwiched with casein-agar plate for one hour at $55^{\circ} \mathrm{C}$. The plate was stained with $1 \%(\mathrm{w} / \mathrm{v})$ Coomassie brilliant blue R250 in solvent contained methanol: acetic acid: water (50:10:40).

\section{Effect of solvents}

Stability of the protease against different solvents (such as methanol, 1-propanol, 2-propanol, ethyleneglycol, ethylacetate, acetone, xylene, toluene, benzene) in reaction mixture was determined by assaying the purified enzyme ( 5 $\mathrm{U}, 15 \mu \mathrm{g}$ ) in the presence of $10 \%, 20 \%$ and $50 \%$ of each solvent at $55^{\circ} \mathrm{C}$ for $20 \mathrm{~min}$ using casein as substrate. Controls had no solvent in reaction mixture. All the reactions were performed in triplicate.

\section{Immobilization}

Immobilization of the protease was performed by entrapment method using polyacrylamide gel. The gel was prepared for $7 \%(\mathrm{w} / \mathrm{v})$ polyacrylamide containing $23 \mathrm{U}(70$ $\mu \mathrm{g}$ ) of the protease. Before adding TEMED and APS, the mixture of acrylamide and protease was mixed for $20 \mathrm{~min}$ gently. After polymerization the resulting gel was cut approximately into $0.5 \mathrm{~cm}$ pieces. The gel pieces were washed with $50 \mathrm{mM}$ Tris- $\mathrm{Cl}(\mathrm{pH} 8)$ for $5 \mathrm{~min}$, twice, to remove the soluble enzyme and the gel pieces were stored in $50 \mathrm{mM}$ Tris-Cl $(\mathrm{pH} 8)$ at $4^{\circ} \mathrm{C}$ for further use. Temperature and $\mathrm{pH}$ optima of soluble enzyme and immobilized one were determined. The stability of the 


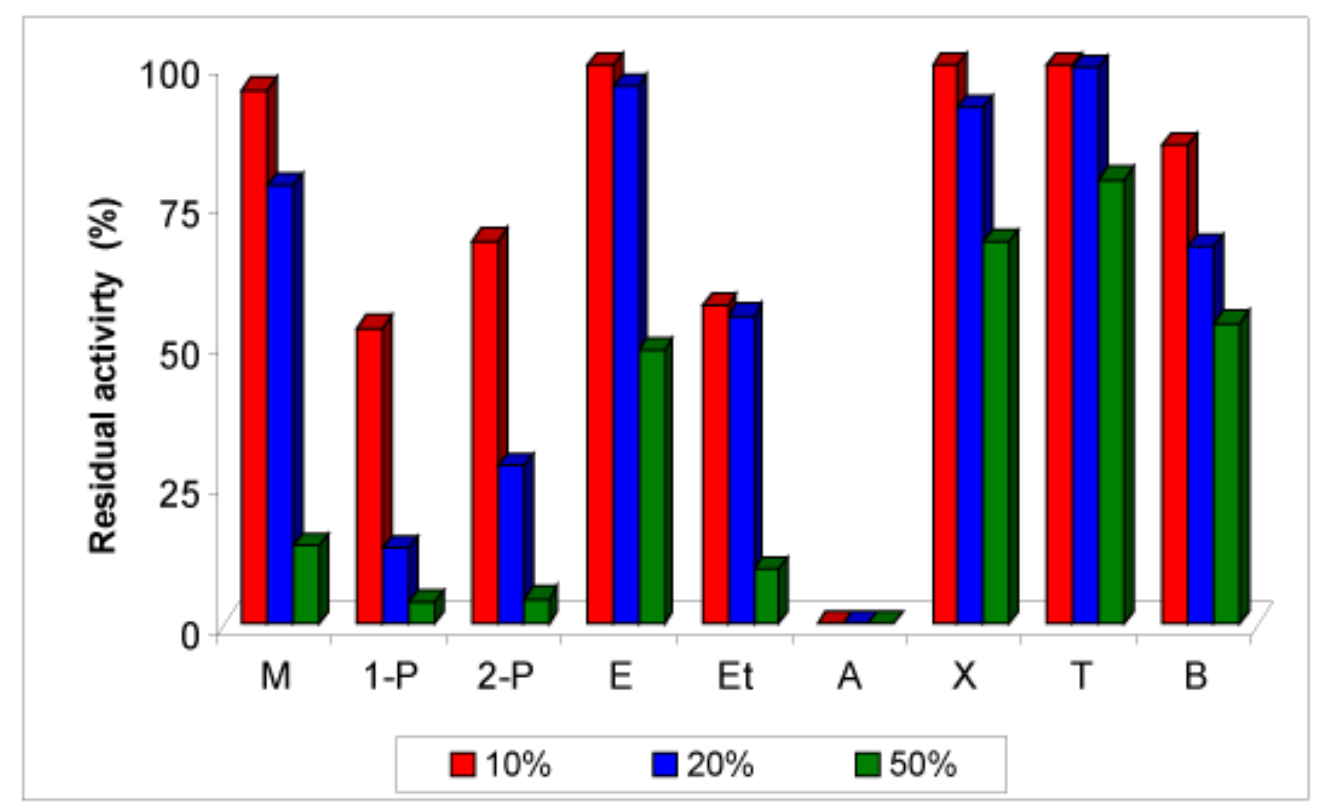

Figure 2. Influence of different solvents on activity of the protease. The enzyme was assayed in the presence of different amount of solvent, $\left[10 \%, 20 \%\right.$ and $50 \%(\mathrm{v} / \mathrm{v})$ of each solvent] for $20 \mathrm{~min}$ at $55^{\circ} \mathrm{C}$. The residual activities were determined with respect to controls. Methanol (M), 1-propanol (1-P), 2-propanol (2-P), ethyleneglycol (E), ethylacetate (Et), acetone (A), xylene (X), toluene (T), benzene (B).

immobilized enzyme was determined at different temperature for various time incubation.

Effect of number of assay cycles on the activity of immobilized protease was determined by assaying the protease for 6 cycles for $20 \mathrm{~min}$ incubation with substrate (hemoglobin) at $55^{\circ} \mathrm{C}$ for each cycle. After every cycle, the immobilized enzyme was washed to remove the substrate and products and used for a fresh assay. The residual activity of the immobilized enzyme was determined according to the control for each cycle.

\section{Digestion of natural proteins}

The crude enzyme (10 U) was incubated with cow and sheep skin, blood clot and coagulated egg white in $20 \mathrm{mM}$ Tris- $\mathrm{HCl}(\mathrm{pH} 8)$ at $37^{\circ} \mathrm{C}$. Conditions of the substrates were monitored at different time incubation.

\section{Removing blood stain}

A clean piece of cloth was soaked in blood and allowed to dry the blood cloth. Then the cloth was soaked in $2 \%$ formaldehyde for $30 \mathrm{~min}$ and washed with water to remove excess formaldehyde. The cloth was cut to equal sizes and they were incubated with the purified protease $(5 \mathrm{U})$ at 45 $50^{\circ} \mathrm{C}$ for different time incubation. After incubation time, each piece was rinsed with water for 2 min and then dried. The same procedure was done for the control except incubation with the enzyme solution.

\section{Dehairing of skin}

Cow's skin was cut to $5 \mathrm{~cm}^{2}$ pieces and incubated with the crud protease $(2 \mathrm{U} / \mathrm{ml})$ in $50 \mathrm{mM}$ Tris- $\mathrm{HCl}(\mathrm{pH} 8)$ at $50^{\circ} \mathrm{C}$. The skin was checked for removal of hair at different incubation times.

\section{RESULTS AND DISCUSSION}

\section{Purification of the protease}

The results of a typical procedure for the purification of $P$. aeruginosa PD100 protease to homogeneity are summarized in Table 1. Stepwise increasing the salt concentration from 0.1 to $0.6 \mathrm{M} \mathrm{NaCl}$ carried out elution of the protease from CM-Sephadex column. This resulted in elution of a pure protease at $0.3 \mathrm{M}$ of $\mathrm{NaCl}$. The enzyme was purified 49 fold with an overall yield of $38 \%$ and a specific activity of $434 \mathrm{U} / \mathrm{mg}$. The purified enzyme could be stored in $50 \mathrm{mM}$ Tris-HCl buffer, $\mathrm{pH} 8$, at $-20^{\circ} \mathrm{C}$ for 3 months without any apparent loss of activity.

Table 2 shows properties of the purified protease used in this work.

\section{Effect of SDS and Tween 80}

With respect to the results from this experiment, it was found that the protease of $P$. aeruginosa PD100 enable to act in the presence of SDS and Tween 80. The enzyme showed $50 \%$ of maximal activity in $1 \%(\mathrm{w} / \mathrm{v})$ SDS and $3 \%$ $(\mathrm{v} / \mathrm{v})$ Tween 80 . The protease sample incubated with $1 \%$ (w/v) SDS and 3\% (v/v) Tween 80 were loaded on SDSPAGE without boiling the samples. After electrophoresis, the gel was divided into two parts, one part was washed 


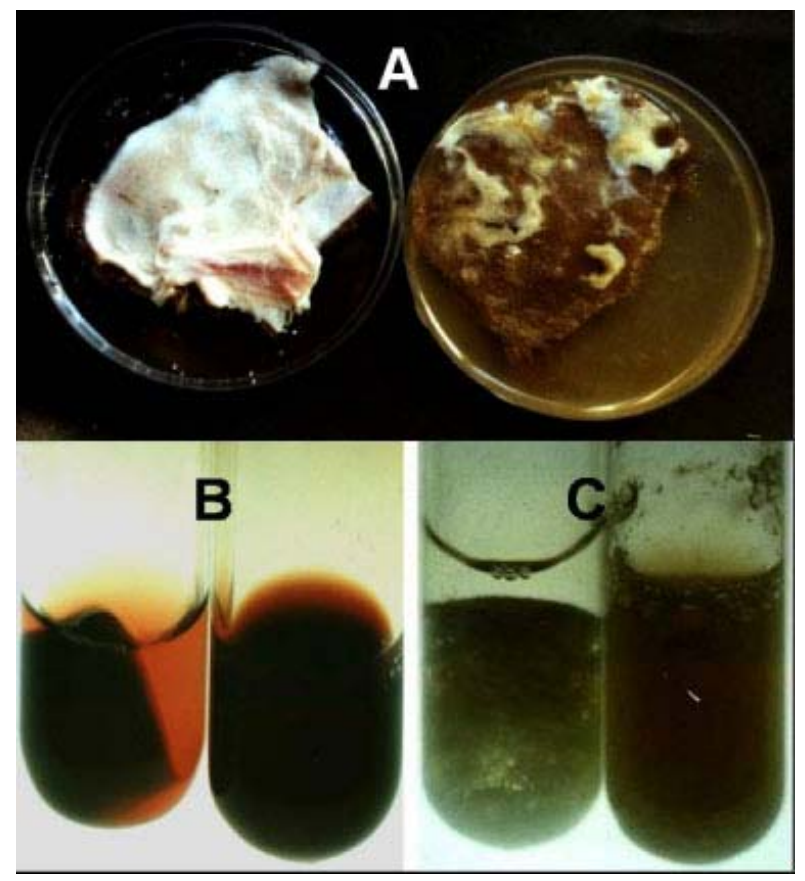

Figure 3. Digestion of natural proteins. (a) The protease was incubated with cow skin at $37^{\circ} \mathrm{C}$ for 14 hrs.

(b) The protease was incubated with blood clot at $37^{\circ} \mathrm{C}$ for 14 hrs.

(c) The protease was incubated with coagulated egg white at $37^{\circ} \mathrm{C}$ for $14 \mathrm{hrs}$.

$($ Left $=$ control, Right $=$ test $)$. For further detail refer to text.

with Triton X-100 and another one used without washing for zymography. Zymogram showed that the protease sample, which treated with SDS, retains its activity after electrophoresis but when it was washed with Triton X-100 clear band was more visible. In contrast Tween 80 treated protease showed the activity band only after washing the gel with Triton X-100 (data not shown). Clear bands on zymogram, indicating that this protease maintained its activity in the presence of SDS and Tween 80 after complete washing with Triton X-100. In case of Tween 80, clear band showed less activity compare to SDS treated protease, suggesting that inactivation of the enzyme in the presence of Tween 80 after electrophoresis is more and it may be due to addition of SDS during electrophoresis, addition of both SDS and Tween 80 inactive the enzyme more than single detergent. Removing SDS by Triton X100 resulted induction in protease activity and make the right renaturation and the protease retained its activity. Incubation of the protease with SDS for $60 \mathrm{~min}$ at $55^{\circ} \mathrm{C}$ showed that the rate of tyrosine released at a particular time for SDS remained constant but in case of Tween 80 inactivation of the protease was time dependent (Figure 1). It has been reported that in some instances the reaction of protease is improved by addition of SDS to the reaction mixture because of partial denaturation of substrate (Vercaigne-Marko et al. 2000). The protease was investigated to determine its usefulness in the clean up of DNA at high temperature due to its stability against SDS and temperature. There are different reports for proteases that can act in the presence of detergent like SDS and they were used for bio-formulation (Anwar and Saleemuddin, 2000).

\section{Influence of solvent}

As shown in Figure 2 the protease has ability to act in the presence of different concentration of solvents in reaction system. The enzyme showed $80-90 \%$ of maximum activity for $20 \%$ of methanol, ethyleneglycol, xylene and toluene. Except acetone the rest of solvents used here showed more than $50 \%$ of total activity in $10 \%$ of solvents in reaction mixture. These results show high stability of the protease against denaturation or unfolding in the presence of solvents. This capability may be due to disulfide bonds, presence of the disulfide bond(s) in this protease was found to be essential for its activity. There are number of reports on importance of disulfide bonds for stability of the protein against solvents (Ogino et al. 2001). This protease is very useful for fermentation and reactions in the presence of solvents. One of the most important advantages of this property is to reduce or abolish microbial contamination during degradation reaction.

\section{Immobilization}

The immobilized enzyme retained $90 \%$ of total activity compared with the soluble enzyme, indicating the efficiency of the immobilized system to be $90 \%$. Also immobilized protease in comparison of the $\mathrm{pH}$ and temperature activity profiles with the soluble enzyme showed no change in the $\mathrm{pH}$ optimum (7.5-8) and temperature optimum $\left(55-60^{\circ} \mathrm{C}\right)$ as results of immobilization. Indicating that immobilization of the enzyme did not alter the $\mathrm{pH}$ or temperature optima of the enzyme. However temperature stability of the immobilized protease compared to the soluble enzyme showed $15-20 \%$ increase (data not shown) as indicated by its inactivation pattern. Enhanced temperature stability of immobilized protease could due to physical protection of polyacrylamide.

Upon repeated use, the entrapped enzyme retained $83 \%$ of its initial activity after six cycles. In the absence of any detectable leaching (evidenced by the absence of enzymatic activity in the supernatant), the decrease in the activity can be correlated to the slight inactivation of the enzyme after every use. The immobilized protease showed excellent storage stability and could be stored at $4^{\circ} \mathrm{C}$ in $20 \mathrm{mM}$ Tris$\mathrm{HCl}$ buffer $(\mathrm{pH} 8)$ for more than 30 days without any loss in its initial activity. It is notable that the soluble protease is stable in $-20^{\circ} \mathrm{C}$ and at $4^{\circ} \mathrm{C}$ after 50 days $90 \%$ of the initial protease activity is detectable. The immobilized enzyme can be recommended for amino acid production, clearing of juice and related applications.

\section{Digestion of natural proteins}




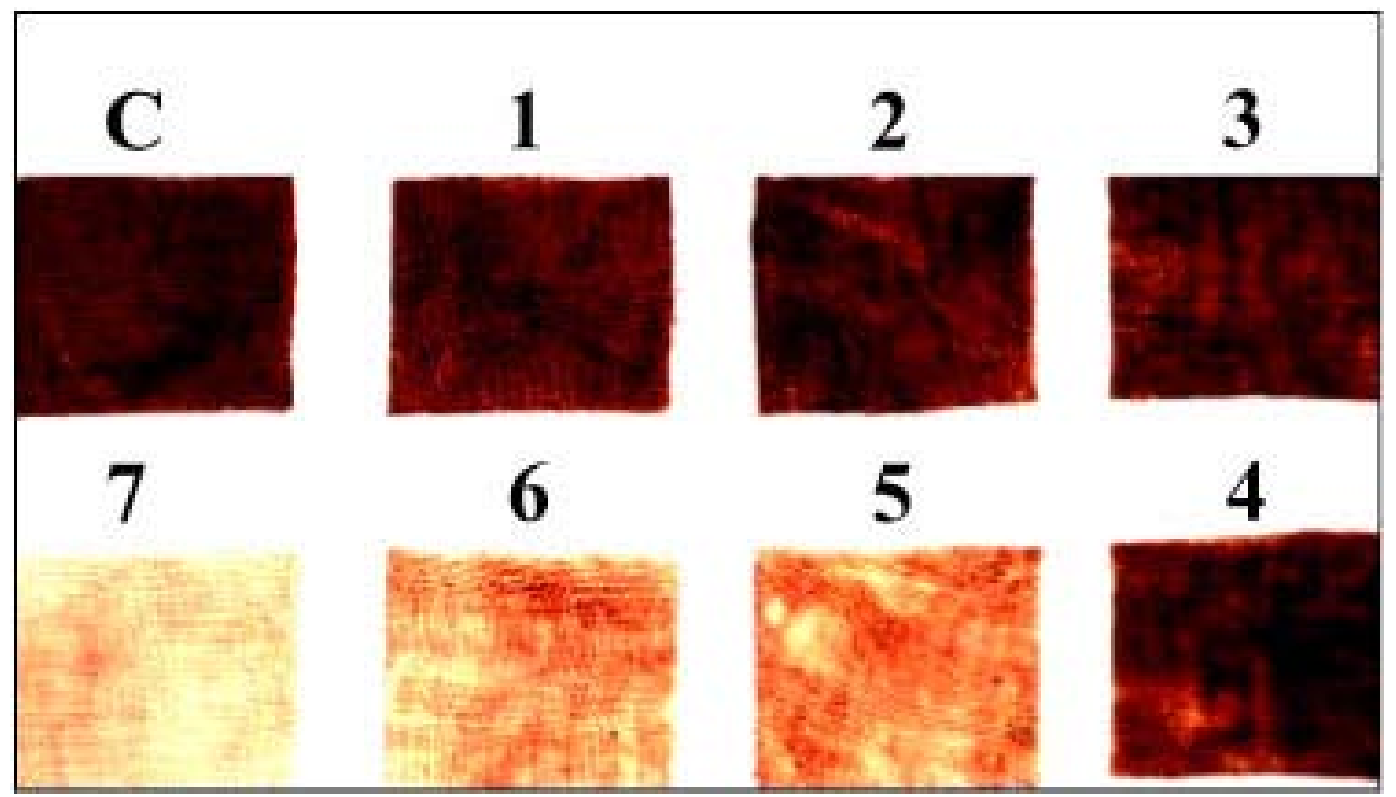

Figure 4. Removing blood stains from cloth. The protease $(5 \mathrm{U} / \mathrm{ml})$ was incubated with the cloth and incubated at $45-50^{\circ} \mathrm{C}$ for different time. For further detail refer to text. $C=$ control, $1=5 \mathrm{~min}, 2=10 \mathrm{~min}, 3=15 \mathrm{~min}, 4=20 \mathrm{~min}, 5=30 \mathrm{~min}, 6=40 \mathrm{~min}, 7=50 \mathrm{~min}$.

As shown in Figure 3 after incubation of the protease with blood clot and coagulated egg white, insoluble forms of them were converted to soluble form. The protease was able to digest cow skin when it was incubated for long time. Capability of the protease to digest different natural substrates with base of fibrin, albumin and collagen suggesting usefulness of this enzyme for different applications such as extraction of collagen from skin for collagen replacement therapy, waste treatment and other related applications.

\section{Removal of blood stain}

In case of removing blood stain from cloth, it was seen that the protease enable to remove blood stain very easily without addition of any detergent (Figure 4). This protease showed high capability for removing proteins and stain from cloth and also it could be used as an alkaline protease in detergent powder or solution. Its ability to act in the presence of solvents and detergents can be exploited for this purpose. Anwar and Saleemuddin, 1997 reported usefulness of protease from Spilosoma obliqua for removal of blood stains from cotton cloth in the presence and absence of detergents but we believe that this protease is more effective.

\section{Dehairing}

Incubation of the protease with skin for dehairing showed that after 2.30-3 hrs incubation of the enzyme $(2 \mathrm{U} / \mathrm{ml})$ with cow skin, hair was removed very easily compare to the control (data not shown). Since this protease can digest collagen, the process of dehairing must be controlled to avoid reducing the quality of the leather. As against traditional chemical methods, enzymatic processes yield products of improved quality and reduce the use of hazardous and polluting chemicals.

Properties of this protease such as alkaline $\mathrm{pH}$, thermostability, solvent and detergent resistance, make the enzyme very useful for different applications. The immobilized enzyme with higher thermostability than the soluble enzyme can be used in protein degradation process with repeated use at high temperature. Since this protease has gelatinase activity, it can be recommended for an interesting application of alkaline protease which was developed by Fujiwara and co-workers (Ishikawa et al. 1993). They reported the use of an alkaline protease to decompose the gelatinous coating of X-ray films, from which silver was recovered. Different reports are available on industrial application of proteases (Gupta et al. 2002) with respect to properties of enzymes. The protease of $P$. aeruginosa PD100 with broad range of substrate specificity can be recommended for recovery of silver from photographic films, for animal food industry and clearing beverages, in leather industry for dehairing and bating skins, production of amino acid and peptides. Also it is useful for cleaning DNA during isolation of the DNA. Since this protease has high collagenolytic activity, it can be used for various applications such as: (a) cosmetics: for skin rejuvenation, wrinkle smoothing and dandruff removal, prophylactic on senile skin changes and also removal of the atrophied epithelium from the skin surface, (b) medicine: festering and wet wounds, (c) leather industry: for manufacturing of skin and leather and getting high quality suede, (d) biochemistry: for isolation of cells from many types of animal tissue. This study was fruitful in identifying one such enzyme, which can be exploited commercially. 


\section{REFERENCES}

ANWAR, A. and SALEEMUDDIN, M. Alkaline protease from Spilosoma obliqua: potential applications in bioformulation. Biotechnology and Applied Biochemistry, April 2000, vol. 31, no. 2, p. 85-89.

ANWAR, A. and SALEEMUDDIN, M., Alkaline proteases. A Review. Bioresource Technology, June 1998, vol. 6 , no. 3, p. 175-183.

ANWAR, A. and SALEEMUDDIN, M. Alkaline-pHacting digestive enzymes of the polyphagous insect pest Spilosoma obliqua : stability and potential as detergent additives. Biotechnology and Applied Biochemistry, February 1997, vol. 25, no. 1, p. 43-46.

BANERJEE, U.C.; SANI, R.K.; AZMI, W. and SONI, R. Thermostable alkaline protease from Bacillus brevis and its characterization as a laundry detergent additive. Process Biochemistry, October 1999, vol. 35, no. 1, p. 213-219.

GUPTA, R.; BEG, Q.K. and LORENZ, P. Bacterial alkaline proteases: molecular approaches and industrial applications. Applied Microbiology and Biotechnology, April 2002, vol. 59, no. 1, p.15-32.

ISHIKAWA, H.; ISHIMI, K.; SUGIURA, M.; SOWA, A. and FUJIWARA, N. Kinetics and mechanism of enzymatic hydrolysis of gelatin layers of X-ray film and release of silver particles. Journal of Fermentation and Bioengineering, 1993, vol. 76, no. 4, p. 300-305.

KUNITZ, M. Crystalline soybean Trypsin Inhibitor, II. General properties. Journal of General Physiology, March 1947, vol. 30, no. 4, p. 291-310.

LAEMMLI, U.K. Cleavage of structural proteins during the assembly of the head of bacteriophage T4. Nature, August 1970, vol. 227, no. 259, p. 680-685.

LOWRY, O.H.; ROSEBROUGH, N.J. ; FARR, A.L. and RANDALL, R.J. Protein measurement with the Folin phenol reagent. Journal of Biological Chemistry, 1971, vol. 193, p. 265-275.

OGINO, H.; UCHIHO, T.; YOKOO, J.; KOBAYASHI, R.; ICHISE, R. and ISHIKAWA, H. Role of intermolecular disulfide bonds of the organic solvent-stable PST-01 protease in its organic solvent stability. Applied and Environmental Microbiology, February 2001, vol. 67, no. 2, p. 942-947.

SJODAHL, J.; EMMER, A.; VINCENT, J. and Roeraade J. Characterization of proteinases from Antarctic krill (Euphausia superba). Protein Expression and Purification, October 2002, vol. 26, no. 1, p. 153-161.

VERCAIGNE-MARKO, D.; KOSCIARZ, E.; NEDJARARROUME, N. and Guillochon, D. Improvement of
Staphylococcus aureus -V8-protease hydrolysis of bovine haemoglobin by its adsorption on to a solid phase in the presence of SDS: peptide mapping and obtention of two haemopoietic peptides. Biotechnology and Applied Biochemistry, April 2000, vol. 31, no. 2, p. 127-134. 